\author{
수치예보모형을 이용한 역학적 규모축소 기법을 통한 \\ 농업기후지수 모사 \\ 안중배 ${ }^{1}$ 허지나 ${ }^{1 *} \cdot$ 심교문 ${ }^{2}$ \\ 1부산대학교 지구환경시스템학부, ${ }^{2}$ 국립농업과학원 \\ (2009년 11월 19일 접수; 2010년 3월 24일 수정; 2010년 3월 24일 수락)
}

\title{
A Simulation of Agro-Climate Index over the Korean Peninsula Using Dynamical Downscaling with a Numerical Weather Prediction Model
}

\author{
Ahn, Joong-Bae ${ }^{1}$, Jina Hur ${ }^{1 *}$ and Kyo-Moon Shim ${ }^{2}$ \\ ${ }^{1}$ Division of Earth Environment, Pusan National University, 30 Changjeon-dong, \\ Keumjeong-ku, Pusan 609-735, Republic of Korea \\ ${ }^{2}$ National Academy of Agricultural Science, RDA, Suwon, Korea \\ (Received November 19, 2009; Revised March 24, 2010; Accepted March 24, 2010)
}

\begin{abstract}
A regional climate model ( $\mathrm{RCM})$ can be a powerful tool to enhance spatial resolution of climate and weather information (IPCC, 2001). In this study we conducted dynamical downscaling using Weather Research and Forecasting Model (WRF) as a RCM in order to obtain high resolution regional agroclimate indices over the Korean Peninsula. For the purpose of obtaining detailed high resolution agroclimate indices, we first reproduced regional weather for the period of March to June, 2002-2008 with dynamic downscaling method under given lateral boundary conditions from NCEP/NCAR (National Centers for Environmental Prediction/National Center for Atmospheric Research) reanalysis data. Normally, numerical model results have shown biases against observational results due to the uncertainties in the modelís initial conditions, physical parameterizations and our physical understanding on nature. Hence in this study, by employing a statistical method, the systematic bias in the modelís results was estimated and corrected for better reproduction of climate on high resolution. As a result of the correction, the systematic bias of the model was properly corrected and the overall spatial patterns in the simulation were well reproduced, resulting in more fine-resolution climatic structures. Based on these results, the fine-resolution agro-climate indices were estimated and presented. Compared with the indices derived from observation, the simulated indices reproduced the major and detailed spatial distributions. Our research shows a possibility to simulate regional climate on high resolution and agro-climate indices by using a proper downscaling method with a dynamical weather forecast model and a statistical correction method to minimize the model bias.
\end{abstract}

Key words : Agro-climate index, Dynamical downscaling, Numerical weather prediction model, Statistical correction method

\section{I. 서 론}

IPCC 제 4차 평가보고서에 의하면 지난 100 년간
지구시스템의 열에너지 변화에 의해 지구의 평균 기온 이 약 $0.74^{\circ} \mathrm{C}$ 가 상승하였으며, 폭염과 집중호우와 같 은 기상이변이 빈번이 발생하고 그 강도 역시 강해지

* Corresponding Author : Jina Hur( hjn586@pusan.ac.kr) 
는 것으로 나타났다. 이러한 기후 변화는 기후 민감도 가 높은 농업·임업 분야를 비롯하여 상대적으로 민감 도가 적은 공업 분야까지 사회 · 경제 전반에 막대한 영향을 미친다. 특히 농업분야에서 기후변화는 농작물 의 생산성 및 안정성과 직결되어 있어 국 · 내외 곡물 가격의 변동 및 식량 위기에 의한 사회 불안과 경제 공황을 야기할 수 있다(Ministry of Agriculture and Forestry, 2001). 기후변화에 따른 적지 않은 파급효과가 예상되는 농업 분야에서 국지적인 기후 예측은 필수불가 결하다. 그러나 생물의 반응은 단일 기상요소 보다는 복 합적인 요인에 의해 지배되므로 단순한 기후자료 제공만 으로는 농민들에게 큰 도움을 주지 못한다. 따라서 농민 에서 생산된 기후 자료를 이용한 상세한 농업기후지수 예측 정보의 제공은 자국농민과 농업 보호 측면에서 중 요하다(Ministry of Science and Technology, 1990).

Yun(2007)과 Kim and Yun(2008)은 $30 \mathrm{~m}$ 격자단 위의 남한 전역 전자기후도를 생산한바 있으며, 이 전 자기후도의 농업적 활용 방안에 대한 지속적인 연구가 이루어지고 있다. 높은 활용성에도 불구하고 이러한 상세자료는 광역적으로 관측된 기상자료를 공간 내삽 을 통하여 구한 것으로 이 추정치에 대한 역학적, 물 리적 근거는 다소 약하다. 또한 그러한 진단적 기후 추정 방식은 기상 변화나 미래의 기후를 예측하기 위 해 사용하기에는 불가능하다. 수십 $\mathrm{m}$ 간격의 상세한 관측이 현실적으로 불가능함에도 불구하고 상세 기후 에 대한 높은 이용가치로 인해 상세 자료에 대한 필 요성은 향후 더욱 강조될 것이다. 따라서 역학적, 물 리적으로 균형 있는 자료를 생산하는 연구는 반드시 필요하다(IPCC, 2007).

계산상의 어려움으로 인해 기후 자료를 생산하기 위 해 현재에는 $200 \mathrm{~km}$ 내외 격자간격의 저해상도를 가 진 전지구 규모의 대순환 모형이 대부분 활용된다. 이 렇게 생산된 자료들은 종관규모의 평균적 대기특성을 알고자 하는 데는 적합하지만 농업활동에 필요한 국지 적인 기후정보를 제공하기에는 크게 미흡하다(Ministry of Science and Technology, 1990). 이러한 대순환 모형의 제약을 극복하고 상세한 기후정보를 얻기 위한 방법으로 특정 지역을 고분해능으로 표현하고 특성화 된 물리 과정을 고려할 수 있는 지역기후모형을 이용 한 역학적 규모축소법이 최근 이용되고 있다(IPCC, 2007; Im et al., 2008a). 대순환 모형의 개선과 더 불어 지역기후모형을 이용한 역학적 규모축소법에 대
한 연구와 적용이 IPCC 3 차 보고서 이후 더욱 활발 히 진행되고 있다(IPCC, 2007).

전지구 대순환 모형과 지역기후모형의 상당한 진보 에도 불구하고 기후예측은 여전히 불확실성을 가지게 되는데, Lorenz(1975)는 이 불확실성이 모형 적분 초 기에 주어지는 초기장과 모형 모수화 과정의 불안정성 등에 의한 계통적 오차(systematic bias)로부터 생성된 다고 하였다(IPCC, 2007). 따라서 기상 모형을 이용 한 지역 기후를 모사하고 이를 통해 농업기후지수를 구하기 위해서는 역학적 모형이 갖고 있는 여러 가지 계통적 오차를 제거하는 것이 필요하다. 한편 $\mathrm{Ahn} e t$ $a l .(2002)$ 은 이러한 역학적 모델이 갖는 계통적 오차를 통계적 보정 방법을 이용하여 제거될 수 있음을 보인 바 있다.

본 연구에서는 한반도 상세 기후를 재현하고 이를 활용하여 농업기후지수를 추정하고자 하였다. 이를 위 해 2002년부터 2008년까지의 National Centers for Environmental Prediction/National Center for Atmospheric Research(NCEP/NCAR) 재분석 자료를 경계 조건으로 하여 기상청 현업 예보 모형인 Weather Research and Forecast Model(WRF)을 이용한 역학 적 규모축소법을 먼저 실시하였다. $3 \mathrm{~km}$ 까지 역학적 규모축소된 모사 결과로부터 모형에 나타나는 계통적 오차를 통계적 방법을 통해 추정한 후 모형결과를 보 정함으로써 역학적 상세 기후자료를 구했다. 이렇게 생산된 기후자료를 이용하여 농업기후지수를 추정하였 으며 그 결과를 관측으로 유도된 종관적 농업기후지수 와 비교함으로써 기상모형을 이용한 농업기후지수의 모사 및 예측 가능성을 살펴보았다.

\section{II. 모형 및 자료생산 방법}

상세 기후 자료를 생산하기 위해 6시간 간격의 $\mathrm{NCEP} / \mathrm{NCAR}$ 재분석 자료를 지역기후모형인 WRF 모형의 초기 및 경계 조건으로 하여 2002년 3월 1일 부터 견간 역학적 규모축소법을 이용하여 적분하였다. 본 수치실험에 사용된 WRF모형은 미국 국립대기연구 센터(NCAR)에서 개발된 기상예측모형이다. 적분 영역 은 서울을 중심점으로 하여 $27 \mathrm{~km}, 9 \mathrm{~km}, 3 \mathrm{~km}$ 의 수 평 격자 간격을 가지는 3 개의 영역으로 설정하였다. 모형의 최종 수평 격자는 지형적 효과가 잘 고려될 수 있도록 $3 \mathrm{~km}$ 의 세밀한 격자 체계로 구축하였다 
Table 1. The summary of the regional climate model

\begin{tabular}{lll}
\hline \hline \multicolumn{1}{c}{ Dynamic core } & \multicolumn{1}{c}{ ARW (Advance Research WRF) } \\
\hline Center point & Seoul metropolitan \\
Horizontal resolution (Vertical resolution) of Domain 1 & $27 \mathrm{~km} \times 27 \mathrm{~km}(28$ levels) \\
Horizontal resolution (Vertical resolution) of Domain 2 & $9 \mathrm{~km} \times 9 \mathrm{~km}(28$ levels) \\
Horizontal resolution (Vertical resolution) of Domain 3 & $3 \mathrm{~km} \times 3 \mathrm{~km}(28$ levels) \\
\hline & Microphysics & WRF Single-Moment 6-class scheme (Hong and Lim, 2006) \\
& Cumulus & Kain-Fritsch scheme (Kain and Fritsch 1990, 1993) \\
Physical scheme & Planetary boundary & Yonsei University scheme (Hong and Dudhia, 2003) \\
& Land surface model & Noah land surface model (Ek et al., 2003) \\
& Shortwave radiation & Dudhia scheme (Dudhia, 1989) \\
& Longwave radiation & Rapid Radiative Transfer Model (Mlawer et al., 1997) \\
\hline
\end{tabular}

(Ahn et al., 2002). 보다 자세한 모형 개요는 Table 1에 나타나있다(Ahn et al., 2009).

지역기후모형에 의해 모사되는 기후 자료는 평균적 인 상태와 실제 대기의 평균적인 상태의 차이로 정의 되는 계통적 오차를 갖는다. 통계적 보정을 통해 지역 기후모형이 갖는 계통적 오차를 제거함으로써 상세 기 후 예측 숙련도를 향상시킬 수 있을 것으로 판단된다 (Ahn et al., 2002). 본 연구에서는 지역기후모형에 의해 생산된 기후 자료와 관측 자료와의 차이를 지역 기후모형의 불확실성에 의한 것이라고 판단하고 계통 적 오차를 추정하는 Ahn et al.(2002)에서 소개된 통 계적 보정 방법을 사용하였다. 따라서 보정된 지표 기 온값은 다음과 같이 표현될 수 있게 된다.

$$
T_{\text {correcred }}=T_{\text {model }}+\bar{T}_{d}+\left(\gamma_{T}^{\prime}-1\right) T_{\text {model }}^{\prime}
$$

여기서 $T_{\text {model }}$ 과 $T_{\text {model }}^{\prime}$ 은 각각 지역기후모형 결과 와 편차, $\bar{T}_{d}$ 은 계통적 오차, $\gamma_{T}^{\prime}$ 은 관측과 모사된 기온 편차의 최소제곱 회귀식으로부터 결정되는 계수 이다. 통계적 보정방법에 대한 보다 자세한 내용은 Ahn et al.(2002)에 소개되어 있다.

역학적 규모축소와 통계적 보정을 통해 생산된 남한 의 상세 기후 자료를 이용하여 농업기후지수로 재생산 하였다. 재생산된 농업기후지수는 식물 생육과 연관된 식물온도의 출현초일, 작물 생육과 연관된 작물온도 출현초일, 작물의 냉해와 연관된 벼 이양기의 저온 출 현율과 종상일 출현시기 등이다.

본 실험에서 생산한 상세 기후 자료와 농업기후지수 자료의 모사능력을 검증하기 위해70개 지점의 지상기 상 관측소로부터 얻은 일별 관측 자료와 345 개 지점 의 자동기상 관측 장치(Automatic Weather Station;
이하 AWS)로 부터 얻은 일별 관측 자료를 객관 분 석한 자료를 활용하였다.

\section{III. 결과 및 고찰}

\section{1. 상세 기후 모사 능력 평가}

상세한 농업기후지수를 산출하기 위해서는 마찬가지 로 상세한 기후 자료가 필요하다. 따라서 농업기후지 수 모사 능력을 평가하기 앞서, 역학적 규모축소와 통 계적 보정을 통해 생산한 장기적인 국지 기후 자료의 모사능력을 평가하였다.

415 개 지점의 지상관측자료를 이용하여 객관분석 한 봄철 기온, 역학적 규모축소법을 수행하여 생산한 봄철 기온, 그리고 통계적 보정을 한 봄철 기온을 2002년부 터 2008년까지 평균하여 Fig. 1에 나타내었다. 관측 기 온 분포도에서는 남부지방과 서해 인근 지역이 주변 지 역보다 상대적으로 높은 우리나라 봄철의 특징적인 공 간 패턴이 잘 나타나고 있다. 역학적 규모축소 결과는 남한의 주요 산맥을 따라 나타나는 산악지역의 낮은 기 온을 상세하게 모사하는 등 복잡한 지형 구조를 잘 나 타내고 있다. 그러나 지역기후모형이 갖는 여러 가지 계통적 문제로 인하여 관측과 보정하기 전의 모델 결과 는 그림에서 보듯이 전반적으로 과소 모사 경향이 나타 난다(Fig. 1(b)). 이러한 경향을 모형의 계통적 오차라 할 수 있다. 그런데 Fig. 1(c)에서 보듯이 통계적 보정 결과는 모형의 계통적 오차가 제거되어 관측의 기온 공 간 패턴을 잘 따르면서 동시에 지역기후모형에서 모사 한 남한의 상세한 지형적 특징을 잘 나타내고 있다.

Fig. 2는 부산과 서울의 2002년부터 2008년까지 3 월 일평균 지표 기온의 시계열을 예로써 나타낸 것이 


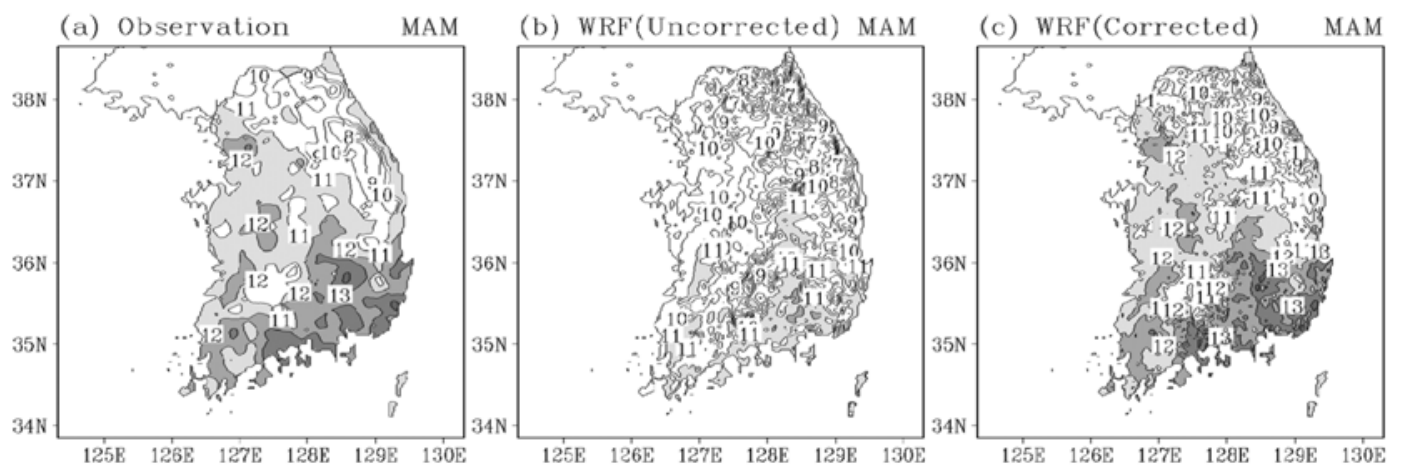

Fig. 1. Distribution of averaged seven years(2002-2008) by (a) observed, (b) uncorrected and (c) corrected surface air temperature (unit: ${ }^{\circ} \mathrm{C}$ ).
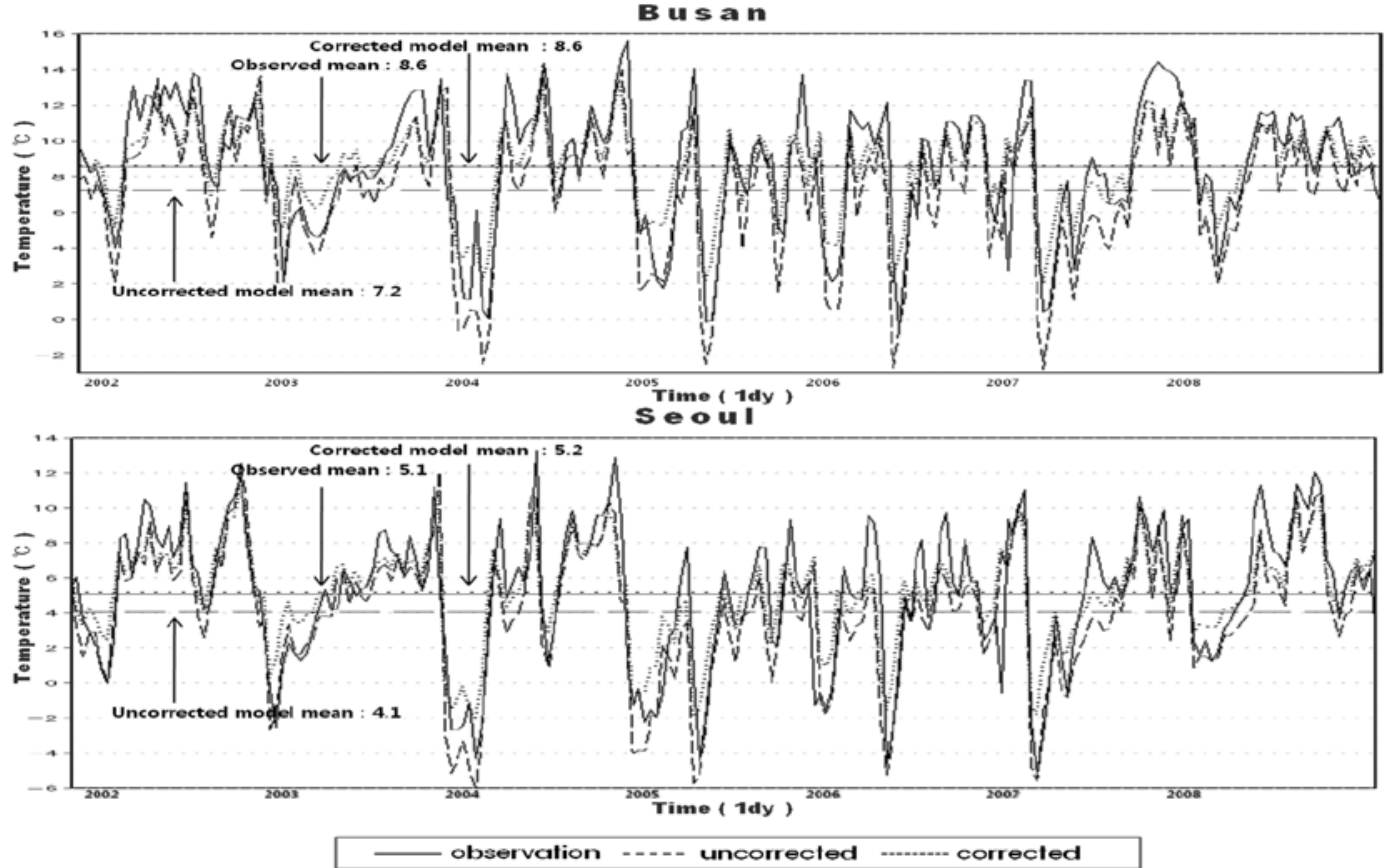

Fig. 2. Time series of observed (dashed line), uncorrected (solid line) and corrected (circle solid line) surface air temperature at the Busan and the Seoul for March(unit: $\left.{ }^{\circ} \mathrm{C}\right)$.

다. Fig. 2에서 보듯이 보정되기 전과 후의 모형의 기 온은 관측된 기온의 시간 전개 패턴을 유사하게 모사 하고 있다. 그러나 통계적 보정 전의 모형 결과는 계 통적 오차에 의해 과소 모사 경향이 나타난다. 이 결 과는 Fig. 1 의 모형의 기온 분포도에서 나타난 결과와 같다. 보정 한 결과는 모형의 시간 전개 패턴을 유지 하면서 과소 모사 경향은 감소시켰다. 즉, Fig. 1과 Fig. 2에서 보듯이 통계적 보정 결과는 모형의 계통적 오차 만을 보정함으로써 모형이 모사하는 변동성에 영
향을 주지 않으면서 관측과의 시공적 일치성을 개선시 키고 있다. 따라서 이러한 교정을 통하여 시간상관계 수의 변화와 공간패턴의 큰 변화 없이 모형의 계통적 오차가 교정이 된 것이다.

Fig. 3는 관측된 기온자료를 객관분석을 통해 격자 화 한 후 모형에서 생산한 기온자료와의 상관계수의 분포를 구한 것이고, Table 2는 여러 관측 지점에서 관측된 기온과 관측지점의 위 - 경도에 해당하는 모형 에서 생산한 기온과의 상관계수를 구한 것이다. 여기서 

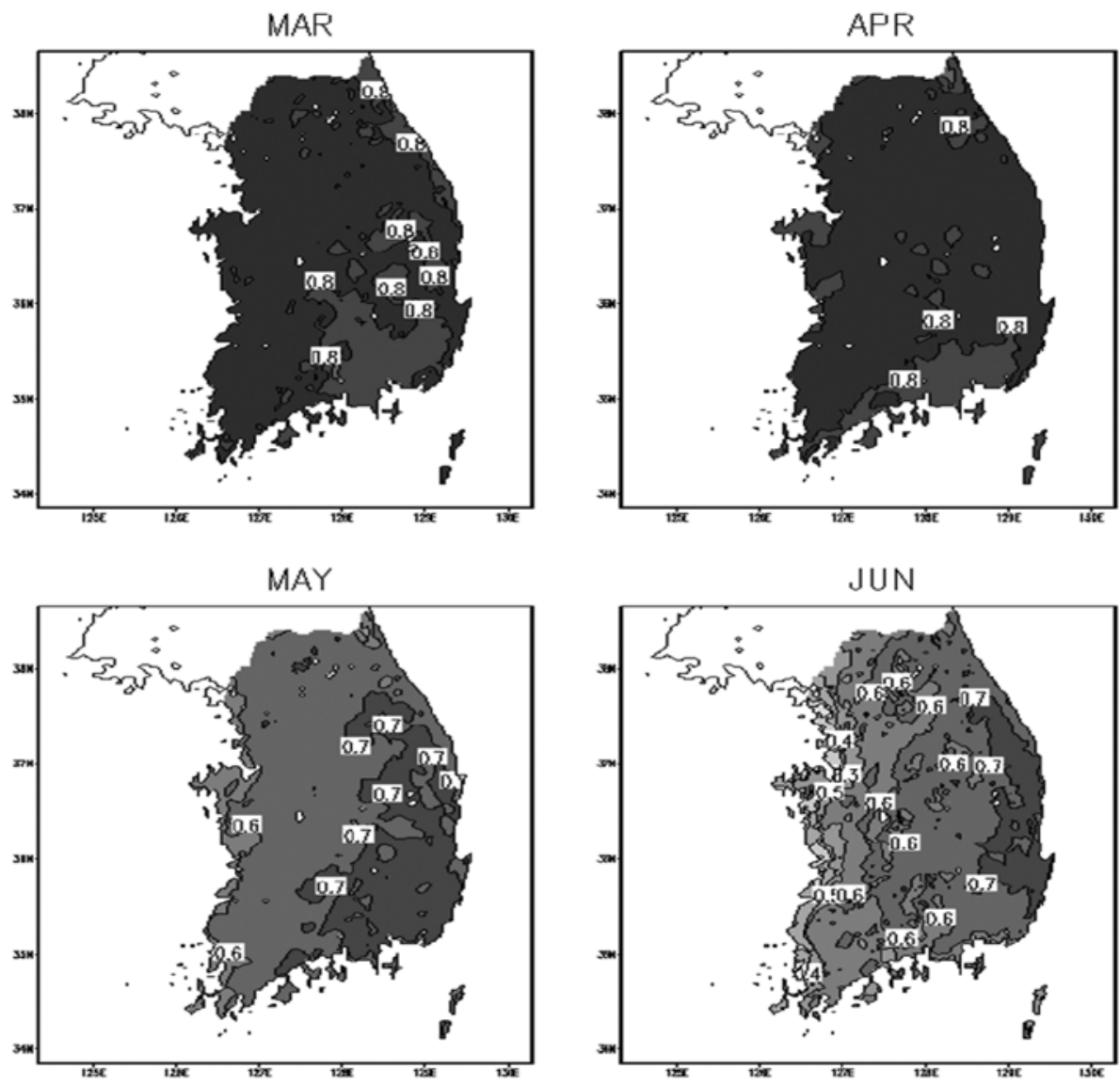

Fig. 3. Correlation coefficients between simulated and observed surface air temperature for the period of 2002-2008.

Table 2. Correlation coefficients between simulated and observed surface air temperature for each station

\begin{tabular}{lcccc}
\hline Station & MAR & APR & MAY & JUN \\
\hline Rusan & 0.84 & 0.8 & 0.72 & 0.57 \\
Chuncheon & 0.82 & 0.82 & 0.68 & 0.57 \\
Daegu & 0.84 & 0.85 & 0.74 & 0.67 \\
Daejeon & 0.85 & 0.83 & 0.66 & 0.57 \\
Gwangju & 0.85 & 0.86 & 0.67 & 0.55 \\
Kangreung & 0.82 & 0.87 & 0.75 & 0.75 \\
Seoul & 0.87 & 0.86 & 0.68 & 0.44 \\
\hline
\end{tabular}

보정 후 결과가 보정 전 결과의 시간패턴을 유지하기 때문에 같은 상관계수를 가지고 있어 Fig. 3와 Table 2는 보정 여부에 상관없이 보인 결과이다. 관측 기온과 지역기후모형에 의해 재현된 3,4 월의 기온은 0.8 이 상의 높은 상관을 보여주고 있어 모형이 관측의 시간 전개 패턴을 잘 모사하는 것을 알 수 있다. 다만 모형
의 시간 전개 패턴 모사 능력이 비선형 강수가 증가하 는 5월, 6 월에 감소하기 때문에 이 시기의 농업기후지 수 모사 능력도 감소할 것으로 생각된다. 그러나 Fisher 변환 공식에 의해 구해진 $99 \%$ 와 $95 \%$ 의 신뢰 구간에 대한 한계 수준이 각각 $0.13,0.18$ 임을 고려할 때, 0.4 에서 0.7 사이의 상관계수를 가지는 5월, 6 월의 지역기후모형 모사결과는 통계적으로 관측과 유의한 상 관을 보이는 것을 알 수 있다(Fisher, 1915).

\section{2. 농업기후지수 모사 능력 평가}

역학적 규모축소법과 통계적 보정을 통해 생산된 상 세 지역 기후 자료를 지수화함으로써 농업기후지수의 생산 능력을 평가하고자 하였다.

\subsection{1. 식물온도 출현초일의 평가}

연 중 일 평균기온이 $5^{\circ} \mathrm{C}$ 이상인 일수는 식물기간이 라고 하고, 이 기간은 식물의 생육과 밀접한 관련이 


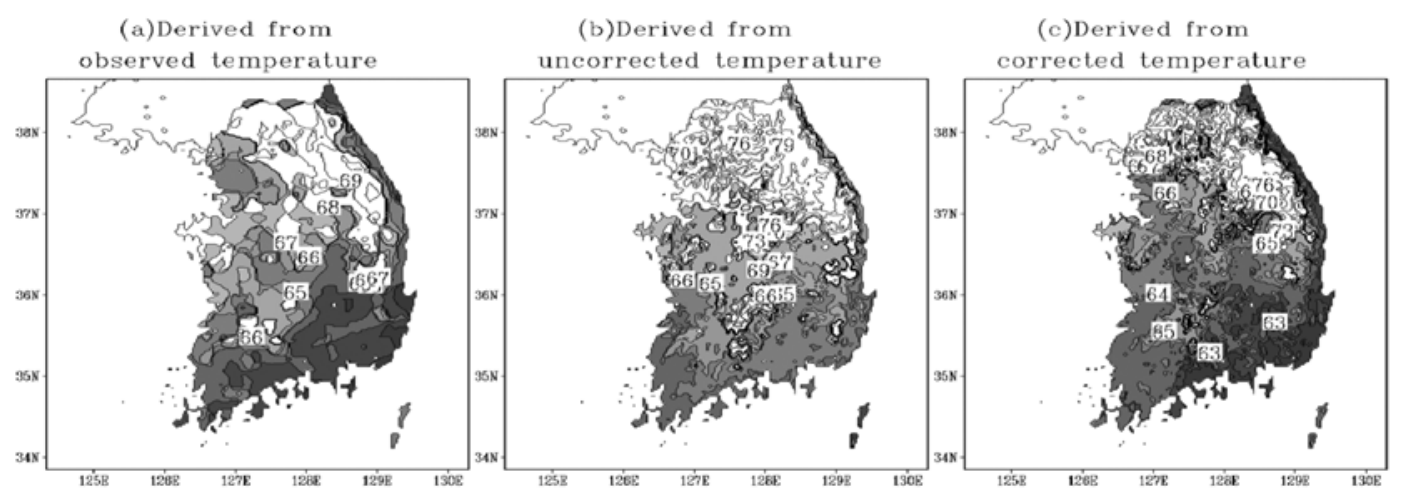

Fig. 4. The first appearance date of vegetation temperature (days over $5^{\circ} \mathrm{C}$ ) for the period of 2002-2008 (unit: Julian day).

있어 연년생 작물의 재배관리에 중요한 지표가 된다 (Shim et al., 2008).

본 수치실험에서 역학적 규모축소 수행 후 생산된 지역기후 자료를 이용하여 식물기간이 시작되는 식물 온도 출현초일을 모사 실험하였다. Fig. 4는 2002년 부터 2008년 기간에 대한 (a) 관측 기온으로부터 유 도된 결과, (b) 보정 전 모형결과, 그리고 (c) 보정 후 모형결과의 식물온도 출현초일을 평균하여 나타낸 것이다. 관측에서 유도된 식물온도 출현일은 평균 67 일이며 동해 인근 지역과 남부 지역에서 빨리 출현 한다. 보정 전 모형의 결과는 관측과 비교해 보았을 때 지역적 편차를 크게 모사하는 반면 지역기후모형 이 가지는 과소모사 경향 때문에 식물온도가 평균 4 일 정도 늦게 71 일에 출현한다. 특히 경기도와 강원 도 지역에서 기온의 과소모사경향을 뚜렷이 확인 할 수 있는데, 경기도 지역의 경우 모형은 관측으로 유 도된 평균 67 일의 식물온도 출현초일을 70 일로 3 일 늦게 모사하였으며, 강원도 지역의 경우 관측으로 유
도된 출현초일 67일을 모형은 4일 늦은 71일로 모 사하였다. 보정 후 모형결과의 남한 평균 식물온도 출현초일은 67 일로 관측으로부터 유도된 66일의 출현 초일 보다 하루 늦게 나타났다. 보정 후 모형결과는 출현초일의 편차가 큰 경기도, 강원도 지역도 평균 66일, 69일로 모사하고 있어 관측으로 유도된 출현초 일과의 편차가 보정 전 모형 결과와 비교해서 감소 하였다. 통계적 보정을 수행한 모형결과는 지역기후모 형이 가지는 큰 지역적 편차를 그대로 유지하면서도 관측에 대하여 늦게 출현하던 경향이 향상되었음을 알 수 있다.

\subsection{2. 작물온도 출현초일의 평가}

작물 생육의 기본온도(base temperature)는 일평균 기온 $10^{\circ} \mathrm{C}$ 를 기준으로 하며, 기본온도 $10^{\circ} \mathrm{C}$ 이상이 되면 일반적으로 여름작물은 생육을 시작하고, 월동작 물인 과수는 발아, 개화 등 발육이 빠르게 진행되는 환경조건이 갖추어지게 된다(Shim et al., 2008). 이
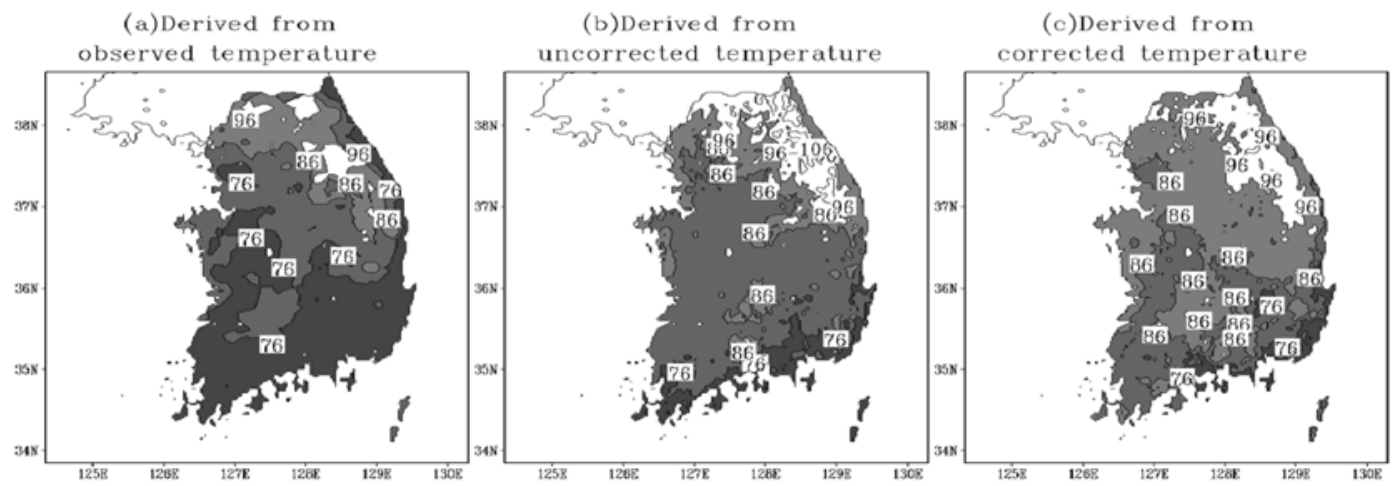

Fig. 5. The first appearance date of crop growth temperature (days over $10^{\circ} \mathrm{C}$ ) for the period of 2002-2008 (unit: Julian day). 
와 같이 작물 생육에 기본온도가 되는 일 평균기온 $10^{\circ} \mathrm{C}$ 을 작물온도라고 하며, $10^{\circ} \mathrm{C}$ 이상인 일수를 작물 온도 출현기간이라고 한다.

지역기후모형의 적분 실험을 통해 생산한 국지 기후 자료를 이용하여 작물온도출현기간이 시작되는 작물온 도 출현초일을 모사 실험하였다. Fig. 5는 일 평균기 온이 $10^{\circ} \mathrm{C}$ 이상이 되는 작물온도 출현초일을 나타낸 것이다. 관측으로 유도된 작물온도 출현초일은 평균 79 일이며, 남부서안, 중부서안, 남해안 지역이 78일 보 다 빠르게 출현하는 지역적 특징을 가진다. 모형에서 모사한 평균 작물온도 출현초일은 관측된 기온으로 유 도한 출현초일 보다 평균 9 일 늦은 88 일로 나타났으 며 관측에서 나타났던 남부서안, 중부서안, 남해안 지 역의 지역적 특징이 잘 모사되고 있지 않다. 특히 모 형의 경우 복잡한 산맥에 따른 산악 효과를 강하게 고려하여 산간 지역의 작물온도 출현을 늦게 모사하는 경향이 있다. 보정 후 모형 결과는 보정 전 모형 결 과보다 출현초일을 평균 3 일 더 늦게 모사하나 보정 전 모형 결과에서 모사하지 못한 관측에서 유도한 작 물온도 출현초일의 지역적 특징을 모사하고 있어 국지 적으로 나타나는 작물온도 출현초일의 세부적인 패턴 을 통계적 보정을 통해 나타낼 수 있음을 보여주는 결과라고 할 수 있다.

한편, 벼는 자연조건 하에서 $15^{\circ} \mathrm{C}$ 이상이 되어야만 정상적인 육묘가 가능하기 때문에 이 유효 온도 $15^{\circ} \mathrm{C}$ 는 벼의 모내기 가능 기온 지표로서 활용된다(Shim et al., 2008). Fig. 6은 2002년부터 2008년까지 (a) 관측으로 유도된 결과, (b) 보정 전 모형 결과, 그리 고 (c) 보정 후 모형 결과의 유효온도 $15^{\circ} \mathrm{C}$ 의 평균 출현초일 분포를 나타낸 그림이다. 관측으로 유도된
작물온도는 평균 104 일로 벼의 침종기인 4 월 초순에 출현한다. 보정 전 모형에서 모사한 평균 작물온도 출 현초일은 관측된 기온으로 유도된 출현초일보다 평균 8 일 늦은 112 일로 나타났으며, 보정 후 모형 결과는 평균 110 일로 나타났다. 특히 부산 - 경남 지역의 경우 모형이 평균 111 일로 관측으로 유도된 출현초일의 평 균 100 일 보다 11 일 늦게 모사하였던 것을 보정을 통해 평균 103 일로 8 일 앞당겼다. 이는 통계적 보정 을 통해 출현초일이 늦게 모사되는 경향을 크게 향상 하였음을 알 수 있다. 한편 모형이 잘 모사하지 못한 중부 논농사 지대의 지역적 편차가 보정 후 모형결과 에도 여전히 나타난다. 이는 보정 후 모형결과가 보정 전 모형결과에서 나타나는 지형적인 요소에 많이 의존 하고 있음을 보여주는 결과이다.

\subsection{3. 벼 이앙기의 저온 출현율 평가}

벼 작물은 활착기에 냉해를 입으면 활착 부진과 생육 지연 현상을 일으키는 피해를 입게 된다(RDA, 1986). 벼 활착기의 저온 피해는 5 월 15 일부터 6 월 5 일까지의 일 평균기온이 $13^{\circ} \mathrm{C}$ 이하인 날의 출현비율로 정의하는 저온 출현율로 정량화된 지표를 활용한다.

벼 이앙기의 냉해피해 지역을 모사 실험하였다. Fig. 7은 2002년에서 2008년 동안 벼 이앙 시기의 평균 저온 출현율을 나타낸 것이다. 저온 출현율이 $9.1 \%$ 이상일 때를 극심한 냉해 피해 지역으로 구분하 는데, 관측된 기온 자료로 유도된 결과는 생육 초기에 상습적으로 냉해를 받는 저온 출현율 $9.1 \%$ 이상인 지 대로 태백 고랭지대와 동해안 북부지대를 보여준다 (Agricultural Technical Institute, 1986). 보정 전 모 형 결과는 관측으로 유도된 저온 출현율이 $2 \%$ 보다

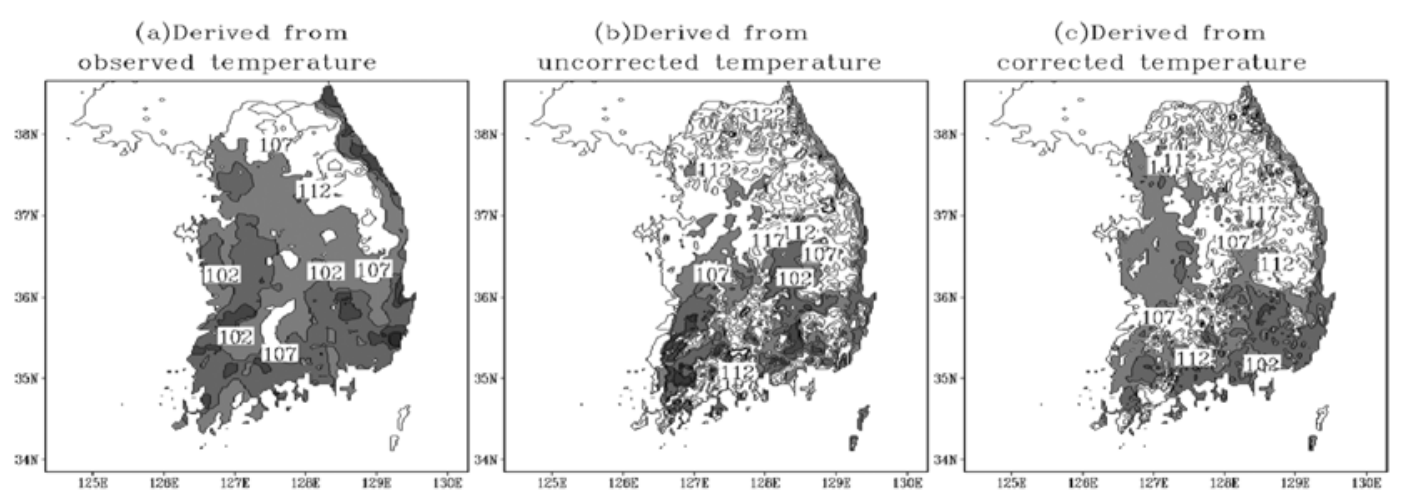

Fig. 6. The appearance date day of daily mean temperature $15^{\circ} \mathrm{C}$ for the period of 2002-2008 (unit: Julian day). 

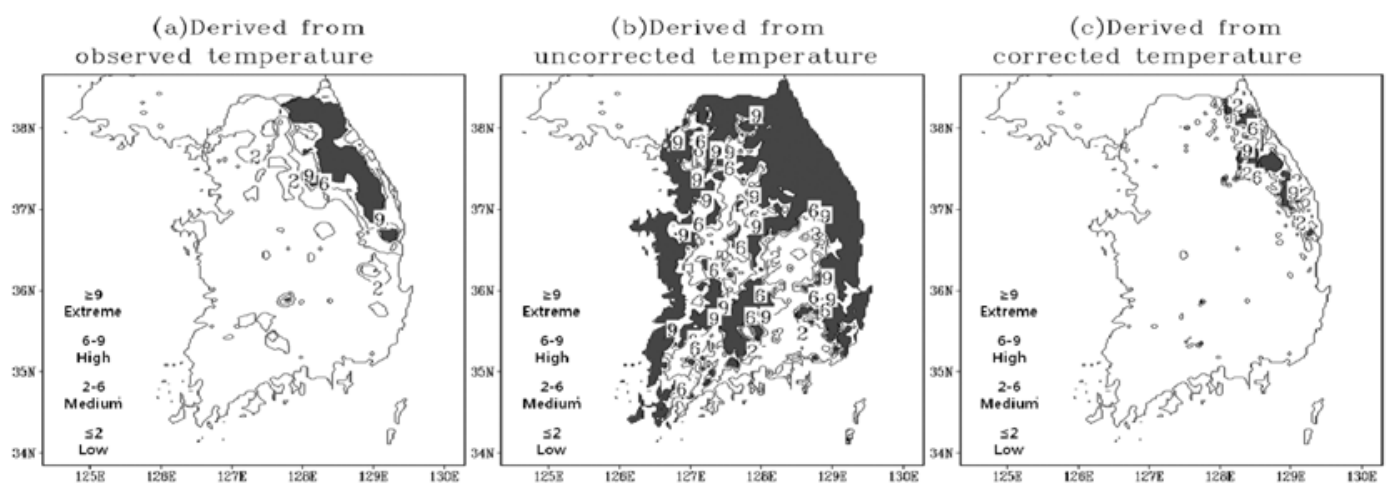

Fig. 7. Occurrence rate of low temperature during rice transplanting period for the period of 2002-2008 (unit: \%).

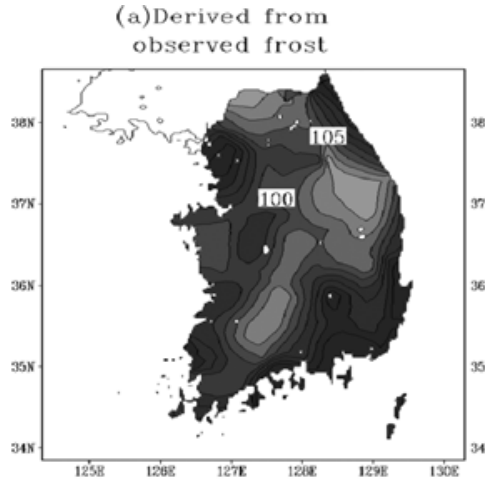

(b)Derived from uncorrected minimum temperature

(c)Derived from corrected

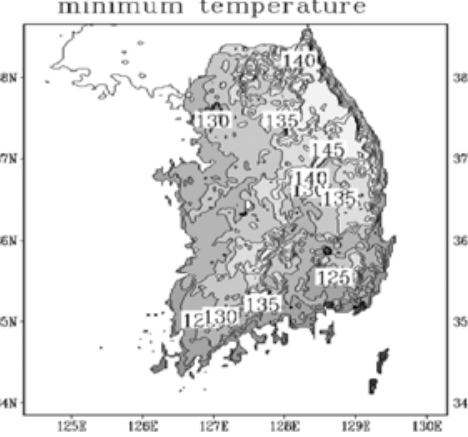
minimum temperature

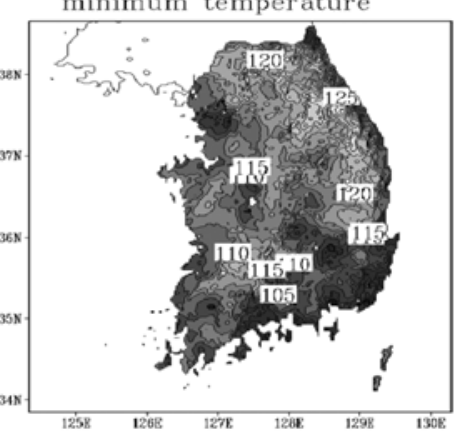

Fig. 8. The last frost date for the period of 2002-2008 (unit: Julian day).

낮은 소백산간지대를 비롯하여 서해 인근 지역 등에서 $9.1 \%$ 이상의 극심한 저온 출현율로 모사하고 있다. 반면 보정 후 모형 결과는 계통적 오차의 제거를 통 해 지역기후모형의 저온 출현율을 과대모사하는 경향 을 제거함으로써 관측과 유사한 정량적 - 정성적 저온 출현율을 나타낸다.

\subsection{4. 종상일의 평가}

서리는 각종 농작물에 막대한 피해를 입히는 경우가 있다. 특히 늦은 봄철에 이동성고기압이 한반도를 뒤 덮을 경우 밤중에 갑자기 기온이 내려 서리가 맺힌다. 이것을 늦서리라고 하며, 이로 인한 피해가 빈번하게 발생한다. 특히 개화기가 빠른 농작물은 늦서리의 피 해를 받기 쉬우며 일반적으로 늦서리의 피해는 지형적 특징으로 인한 고랭지나 분지에서 특히 심하다.

종상일 모사 실험을 통해 늦서리 피해지역 모사능력 평가를 실시하였다. Fig. 8은 (a) 관측으로 유도된 결 과, (b) 보정 전의 모형 결과, 그리고 (c) 보정 후의 모형 결과의 평균 종상일을 나타낸다. 관측의 평균 종
상일에서 저위도지방보다 고위도지방이 저지대보다 고 지대가 종상일이 늦게 나타나는 특징을 확인 할 수 있었다. 모형은 관측이 가지는 공간적 경향성을 잘 모 사하고 있지만 평균 종상일을 30 일 정도 늦게 모사하 고 있는데 이는 지역기후모형의 계통 오차에 의해 야 기된 오차라고 보여진다. 보정 후 모형 결과는 계통적 오차가 제거되어 서리의 국지적 - 지형적인 정성적인 특징을 잘 모사하고 관측과 유사한 수준의 종상일로 모사하고 있다.

\section{적 요}

본 연구에서는 기상예측 모형을 이용하여 상세한 농 업기후지수를 모사하고자 하였다. 이를 위해서 $\mathrm{NCEP} /$ $\mathrm{NCAR}$ 재분석 자료를 지역기후모형인 $\mathrm{WRF}$ 의 초기 및 경계조건으로 하여 2002년 3월부터 7년간 상세한 기후 자료를 생산하고, 이렇게 구한 기후 자료를 통계 적 보정을 거쳐 계통적 오차를 제거함으로써 그 기간 의 기후를 재현하였으며 이를 이용하여 상세한 농업기 
후지수로 생산하였다. 수치 실험을 통해 생산된 상세 지역기후자료는 대순환 모형이 모사할 수 없는 남한의 복잡한 지형적 구조와 전체적인 관측 공간 패턴을 모 사하였다. 통계적 보정은 모형결과가 관측에 비해 과 소모사 되던 경향을 제거함으로써 보다 상세하고 관측 에 가까운 시·공적 기후자료의 생산을 가능하게 하였 다. 이렇게 모사된 기후 자료를 이용하여 식물온도 출 현초일, 작물온도 출현초일, 벼 이앙기의 저온 출현율, 종상일 등의 농업기후지수들에 대한 상세한 분포를 생 산하였다. 보정 전 모형 결과에서는 계통적 오차인 모 형의 기온 과소모사 경향에 의해 전반적인 유효온도와 종상일이 늦게 출현하였으며, 저온 출현율의 빈도가 높게 나타났다. 보정 후 모형 결과에서는 계통적 오차 의 보정에 의해 유효온도 $10^{\circ} \mathrm{C}$ 출현일을 제외한 유효 온도 출현일과 종상일이 앞당겨졌으며, 저온 출현일 빈도가 감소하였다. 보정 후 모형 결과에서 유도된 유 효온도 $10^{\circ} \mathrm{C}$ 출현일은 보정 전 모형결과보다 3 일 늦 게 모사되고 있으나 보정 전 모형 결과에서 모사하지 못한 지역적 특징을 모사하고 있어 국지적으로 나타나 는 작물온도 출현초일의 세부적인 패턴을 이해하는데 유용한 결과라고 판단된다. 모형의 결과로 유도된 농 업기후지수는 복잡한 지역적 편차를 가지면서 정량적 정성적으로 관측에서 유도한 결과와 유사하게 나타났 다. 반면 통계적 보정을 적용하여도 중부 논농사 지대 의 작물온도 출현초일은 여전히 잘 모사되지 못하고 있는데 이는 모형의 결과가 계통적 오차 이외에도 또 다른 불확실성에 의한 문제를 내제하고 있음을 보여주 는 결과이다. 향후 물리적 모수화 과정의 개선, 역학 적 규모축소방법의 최적화 그리고 통계적 보정 방법의 다양한 적용을 통해 보다 항상된 농업기후지수를 생산 할 수 있을 것으로 판단된다. 이러한 실험 결과는 농 업 경영자들에게 상세 농업기후지수 분포의 이해를 도 와줄 뿐만 아니라 본 연구의 실험 방식이 농업 예측 에 활용될 경우 장기 예측 및 기후변화에 따른 예측 을 위한 정보에 긴요하게 사용될 수 있을 것으로 생 각된다.

\section{감사의 글}

본 연구는 농촌진흥청 공동연구사업(과제번호 : 200806A01036056과 200901OFT072454094) 지원에 의해 수행되었습니다.

\section{REFERENCES}

Agricultural Technical Institute, 1986: Features of Korean Agro-climate and Countermeasure of Capital Meteorological Disasters. Rural Development Administration, $194 \mathrm{pp}$.

Ahn, J. B., C. K. Park, and E. S. Im, 2002: Reproduction of Regional Scale Surface air Temperature by Estimating Systematic Bias of Mesoscale Numerical Model. Journal of Korean Meteorological Society 38(1), 69-80.

Boo, K. O., W. T. Kwon, J. H. Oh, H. J. Baek, 2004: Response of global warming on regional climate change over Korea: An experiment with the MM5 model. Geophysical Research Letters 31, L21206.

Dudiha, J., 1989: Numerical study of convection observed during the winter monsoon experiment using a msoscale two-dimensional model. Journal of the Atmospheric Sciences 46, 3077-3107.

Ek, M. B., K. E. Mitchell, Y. Lin, E. Rogers, P. Grunmann, V. Koren, G. Gayno, and J. D. Tarpley, 2003: Implementation of Noah land surface model advances in the National Centers for Environmental Prediction operational mesoscale Eta model. Journal of Geophysical Research 108(D22), $8851 \mathrm{pp}$.

Fisher, R. A. 1915: Frequency distribution of the values of the correlation coefficient in samples of an indefinitely large population. Biometrika 10(4), 507-521.

Hong, S. Y. and H. L. Pan, 1996: Nonlocal boundary layer vertical diffusion in a medium-range forecast model. Monthly Weather Review 124, 2322-2339.

Hong, S. Y. and J. Dudhia, 2003: Testing of a new nonlocal boundary layer vertical diffusion scheme in numerical weather prediction applications. 20th Conference on Weather Analysis and Forecasting/16th Conference on Numerical Weather Prediction, Seattle, WA, 17.3pp.

Hong, S. Y., and J. O. J. Lim, 2006: The WRF Single-Moment 6-Class Microphysics Scheme (WSM6). Journal of Korean Meteorological Society 42(2), 129-151.

Hur, J., J. B. Ahn, and C. Kim, 2009: Reproduction of Regional Scale Climate over Korean Peninsula by Correcting Systematic Bias of Regional Climate Model. 2009 Fall Conference, Deagu, Korean Meteorological Society, 282-283.

Im, E. S., J. B. Ahn, A. R. Remedio, and W. T. Kwon, 2008a: Sensitivity of the regional climate of East/Southeast Asia to convective parameterizations in the RegCM3 modelling system. Part 1: Focus on the Korean peninsula. International Journal of Climatology 28(14), 1861-1877.

Im, E. S., J. B. Ahn, W. T. Kwon, and F. Giorgi, 2008b: Multi-decadal scenario simulation over Korea using a one-way double-nested regional climate model system. Part 2: future climate projection (2021-2050). Climate Dynamics 30(2/3), 239-254.

IPCC, 2007: Climate Change 2007: The Physical Science 
Basis. Contribution of Working Group I to the Fourth Assessment Report of the Intergovernmental Panel on Climate Change, S. Solomon, D. Qin, M. Manning, Z. Chen, M. Marquis, K. B. Averyt, M. Tignor and H. L. Miller (Eds.), Cambridge University Press, Cambridge, United Kingdom.

Jeong K. W., W. K. Kim, J. C. Nam, B. C. Choi, M. Y. Lee, Y. S. Chun, K. B. Yoo, J. T. Choi, J. S. Jeon, J. I. Yun, M. Y. Shin, B. Y. Lee, J. T. Lee, S. H. Kim, M. D. Yong, S. J. Jun, O. H. Kim, and J. H. Yang, 1990: Development of an Operational Weather Information System for Agricultural Applications in Cheju Island(III). Ministry of Science and Technology, 28pp.

Kain, J. S., and J. M. Fritsch, 1990: A one-dimensional entraining/ detraining plume model and its application in convective parameterization. Journal of the Atmospheric Sciences 47, 2784-2802.

Kain, J. S., and J. M. Fritsch, 1993: Convective parameterization for mesoscale models: The Kain-Fritcsh scheme. The representation of cumulus convection in numerical models, K. A. Emanuel and D. J. Raymond (Eds.), American Meteor Society, $246 \mathrm{pp}$.

Kim, J. H., and J. I. Yun, 2008: On Mapping Growing DegreeDays (GDD) from Monthly Digital Climatic Surfaces for South Korea. Korean Journal of Agricultural and Forest Meteorology 10(1), 1-8.

Ministry of Agriculture and Forestry, 2001: Development of Regional Climate Prediction and Application System for Agriculture. Ministry of Agriculture and Forestry, 8pp.

Ministry of Science and Technology, 1990: Development of an Operational Weather Information System for Agricultural
Applications in Cheju Island(III). Ministry of Science and Technology, 28pp.

Mlawer, E. J., S. J. Taubman, P. D. Brown, M. J. Iacono, and S. A. Clough, 1997: Radiative trans-fer for inhomogeneous atmosphere: RRTM, a validated correlated-k model for the long-wave. Journal of Geophysical Research 102(D14), 16663-16682.

Park, C. K., J. B. Ahn, H. S. Jung, J. T. Lee, and M. K. Kim, 2001: Development of Regional Climate Prediction and Application System for Agriculture. Ministry of Agriculture and Forestry, 8pp.

Rural Development Administration, 1986: Feature of Korea's agricultural climatology and meteorological disaster measures of capital. Rural Development Administration, 194pp.

Timbal, B., A. Dufour, and B. McAvaney, 2003: An estimate of future climate change for western France using a statistical downscaling technique. Climate Dynamics 20, 807-823.

Shim, K. M., G. Y. Kim, K. A. Roh, H. C. Jeong, and D. B. Lee, 2008: Evaluation of Agro-Climatic Indices under Climate Change Korean. Korean Journal of Agricultural and Forest Meteorology 10(4), 113-120. (in Korean with English abstract)

Yun, J. I., 2007: Applications of "High Definition Digital Climate Maps" in restructuring of Korean agriculture. Korean Journal of Agricultural and Forest Meteorology 9, 1-16. (in Korean with English abstract)

http://encyber.com/search_w/reference/bottom $1 . p h p ?$ masterno= 89142(2003.08.08) 